\title{
Investigating the influence of a leadership development programme within the Danish public sector
}

Roddy Walker,

PhD student,

Department of

Organisation,

Copenhagen

Business School

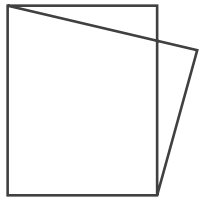

The article outlines the approach taken in an ongoing PhD study, investigating organisational influences of a diploma programme in leadership offered to employees within the Danish public sector. The intention is to consider the implications of wider societal conditions and organisational contexts, rather than solely focusing on events taking place on-site in the development programme. By undertaking a multisited ethnography and adopting a case study approach, individual trajectories of participation through the programme become traceable, training focus on individual leaders' iterative movement between the organisational and educational practices, and the manner in which they translate between these contexts.

\section{Introduction}

Since the 1990's, increasing emphasis has been placed on the importance of leadership in the Danish public sector as a way of meeting increasing demands for efficiency and innovation, resulting in massive investment into these kinds of leadership development programmes (LDP's) from the Danish government. The influence of such programmes on organisational practices, however, remains largely unstudied. The ongoing $\mathrm{PhD}$ project, from which this article emerges, focuses on a diploma programme in public leadership; by adopting an ethnographic approach, the goal is to study how individual leaders participating in the final module of the diploma programme offered at Metropolitan University College in 
Investigating the influence of a leadership development programme within the Danish public sector

Copenhagen translate between the educational and organisational contexts. By completing three case studies, the aim is not solely to study the intended effects of the LDP, nor the learning outcomes of individual leaders, but also the manifestation of these in their subsequent activities. The paper begins with a review of approaches to studying the influence of leadership development, before outlining the theoretical and methodological approach undertaken. The article then outlines contextual conditions, before concluding with a preliminary presentation and analysis of a selection of the empirical material gathered up to this point.

\section{Review of approaches to} studying the influence of LDP's

By tracing the foci of research approaches towards the study of LD, a tendency towards following three main strands of investigation is revealed ( $B$. Carroll and Levy 2010; Nicholson and Carroll 2013). Functionalist approaches focus upon the development of individual leaders' repertoires of techniques and tools in order to increase their effectivity, see (Conger 1992; Lord and Hall 2005). Constructivist approaches, regard LD as facilitating an identity transition (Kempster 2009). Social constructionist approaches focus on the role of discourse, understanding LD as interaction with and within different discourses, (see Fairhurst and Putnam 2004; Carroll and Levy 2010; Thomas and Linstead 2002). A commonality of these approaches has, theoretical convergences aside, been that the focus of research falls upon the changes occurring within individual leaders participating in LDP's. This approach is mirrored by a study undertaken specifically within the national context of Denmark, by the Danish institute for evaluation (Danmarks Evalueringsinstitut 2012), measuring the influence of the diploma programme in leadership through a survey based on the evaluation of participants. These tendencies suggest that the actual influence of these LDP's at the organisational level has remained largely in the background. (Carroll, Levy, and Richmond 2008; Porter and McLaughlin 2006). A more recent study of note within the Danish national context (Weinreich, 2014) uses a more varied methodical approach, incorporating qualitative and quantitative elements, including observations of selected leaders at work after completion of the LDP. The review of approaches suggests that a new dimension could be added to this area of research through the development of a detailed study within the actualities of specific organisational contexts - potentially widening what is to be understood as an organisational influence, as well as enabling a deeper understanding of how this may arise.

\section{A Practice Theory Approach}

The adoption of a practice theory approach presents a theoretical framework geared towards responding to the challenges of focusing upon "situated activity, rather than abstract processes" (Whittington 2003). This represents an ontological choice (Nicolini 2012, 13) to approach social phenomena in a certain way, focusing upon the primacy of practice in the production of meaning, and in the understanding of social activity and interaction. The particular position adopted within this broad theoretical field (Gherardi 2015) is closest to that of social practice theory (Schatzki 2002;
Reckwitz 2002; Brown and Duguid 2001). Compared to post-humanist positions with a focus on symmetry between humans and non-humans (see Feldman and Orlikowski 2011), this position affords primacy to humans as the carriers of practices. By embracing social theories of learning (Lave and Wenger 1991; Wenger 1998; Dreier 2003) within a practice theory framework, individual leaders can be regarded as actively spanning boundaries between their local organisational practices and the educational practices of the LDP, enabling lines of transmission between them. In particular, the theoretical vocabulary offered by Lave and Wenger provides a useful analytical perspective to grasp the individual leader as a kind of "boundary subject" spanning and forming lines of transmission between the practices of the organisation and those of the LDP.

\section{Multi-sited Ethnographies}

Alternative approaches within educational evaluation methodology present interesting models for meeting the challenge of revealing the influence of LDP's on the wider organisation. A process analysis model (Borgnakke 1996) presents a compelling approach to tackling the complexity of this task, building on an ethnographic approach. The aim is to gain insight into convergence and divergence within the circuitry from the intended outcomes and practices of the programme, to the actualities presented at micro level. The embeddedness of such an investigation calls upon an open, multi-sited ethnography (Marcus 1995). Selecting three cases, observing their activities during the final module of the LDP, analysing exam material submitted during the course of the 
Tema: Innovation og uddannelse

programme, and shadowing them in their organisational practice provides a rich empirical basis. This enables methodological triangulation in the study of the development of leadership identity, and the influence this may have on organisational practice - thus going beyond individual accounts. In order to situate the ethnographic research into organisational practice in the most productive manner, the day-care sector is selected as a common institutional context, allowing the influence of common reforms and legislation to be considered. During observation of the final module of the LDP and based upon consideration of the nature of their projects and their profiles as leaders, three individuals were approached and consented to participate in case studies.

\section{Shifting demands for public leaders}

The increased emphasis on the importance of leadership within the Danish public sector can be regarded as the result of a gradual shift in the understanding of this role and of the tasks involved. This involves a change from a figure initially concerned with administrative control, to that of its current manifestation as a professional leader (Rennison 2010), who “must step out of the specific profession - out of the professional uniform and into that of professional management where a manager has multiple disciplines and multiple positions"(ibid; 270). This transformation is explained upon the background of the decentralisation of rigid bureaucratic structures, leading to the requirement for an increasingly autonomous and reflexive individual leader. This should not be understood as a position of complete autonomy, with the overarching shift from government to governance underlining the implicit demands and obligations increasingly put in place by centralised technologies of control. Whilst the specific nature of the role and the demands facing leaders of day-care institutions must be explored more fully (see Hansbøl 2002; Kofod 2002; Cecchin 2008; Larsen Nielsen 2009), this provides a fundamental understanding for the changing conditions for leaders in the day-care sector, emphasising a professionalization process (Klaudi Klausen 2008).

\section{Cluster reforms}

Implications of reforms to the managerial structure within the daycare sector are ubiquitous throughout the ongoing field studies, and should therefore be considered. In 2010, due to increasing child numbers in Copenhagen and strict nation-wide limitations upon the funding of municipalities, the Department for Child and Youth Administration in the municipality of Copenhagen faced large budgetary cuts the following year.' A reform of the managerial structure of municipal day-care institutions was introduced to partly offset this shortfall. By connecting individual institutions within a larger local cluster to be overseen by a central cluster leader (Klyngeleder) assuming overall responsibility for financial and administrative management, the aim was to make this more professional, centralised and effective. ${ }^{2}$ The on-site Educational leaders (Pœdagogiske leder) were to have the core responsibility of focusing on their staff, the educational work with children and contact with parents. ${ }^{3}$ In 2014, a second round of cluster reforms was introduced, creating fewer, larger clusters.
The diploma programme and Metropolitan University College. Following widespread reforms introduced by the Danish government in 2007 (Regeringen 2007) aimed at improving the quality of services offered in the public sector, all leaders were given the right to undertake a diploma education in leadership. The municipality of Copenhagen ${ }^{4}$ committed to making this diploma available to all employees working as leaders in institutions within the public sector by 2015 . As this has largely been achieved, the diploma has effectively become a de-facto requirement for employment as a leader in the municipality. The diploma is accessible at various institutions across Denmark which must be approved and certified by the Ministry of Science, Innovation and Higher Education, and adhere to collective academic guidelines. ${ }^{5}$ In this common legislation, the purpose of the programme is described as qualifying public leaders to independently "analyse, evaluate and apply elements inherent to the process of leadership on a strategic, tactical and operational level, in a reflective and actionable manner" (Academic guidelines, 2015, 5).

The structure of the diploma programme is formed by a set of ten modules, seven of which are obligatory, with the individual student able to select a further three offered within the wider programme, based on own interest. The programme has a practical emphasis; each module concluding with a spoken or written exam in which the participant must identify a specific organisational issue or leadership challenge with which they should engage, the themes and content covered. The final exam project has a similar form, but must involve 


\section{By embracing social theories of learning within a practice theory framework, individual leaders can be regarded as actively spanning boundaries between their local organisational practices and the educational practices of the LDP, enabling lines of transmission between them.}

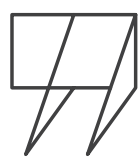

the collection of empirical material and the application of a synthesis of the resources, concepts and tools offered in the constituent modules (Academic guidelines, 2015, 7).

In an attempt to ensure greater organisational coherence, ${ }^{6}$ the municipality of Copenhagen opted to select a single provider of the LDP in 2014, inviting tenders from educational institutions. The Metropolitan University College was the successful applicant and the sole supplier of the LDP for the following three years. One of the conditions of this agreement was that the programme should encourage the municipality of Copenhagen's "Agenda of Trust"7 - with particular emphasis placed on promoting the concept of trust-based leadership.
Eve: Outlining a Case Trajectory In order to illustrate the scope of the empirical material collected thus far, an indication of the approach to tracing the trajectory of one of the case studies between the LDP and organisational practice will now be outlined. Eve has been employed as the leader of the day-care institution "A House" for more than ten years, with approximately 150 children between the ages of 0-6. After the reform of 2011, the "A house" became a member of a cluster, comprising other day-care institutions from the local area, all coming under the remote leadership of an external Cluster Leader, with Eve the Educational leader of "A house". The influence of the cluster reform and the unfolding restructuring of every day organisational routines play a central role in the exam papers written by Eve throughout the LDP.

\section{Exam material}

As artefacts produced within the practices and sense-making processes (Nicolini 2012, 7) involved in the LDP, analysis of the exam material can reveal how participants position themselves within the discursive practices (Gherardi and Nicolini 2002) of the programme how and why they appropriate concepts, tools and resources and intend to apply them in their organisation. Analysis of the exam material provided by Eve - in the form of five written assignmentsprovides insight into her iterative movement between the educational and organisational contexts, her trajectory through the programme. These provide 


\section{From the theoretical perspective provided by Lave and Wenger, Eve's learning curriculum, guided by the actualities of her organisational context, informs her investments and participation in the programme and the appropriation and application of particular resources offered, to meet the demands presented in the organisational context.}

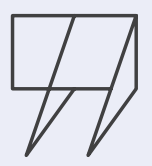

the opportunity to trace marked changes taking place in her understanding of the organisation and staff, as well as her role as leader. By providing an excerpt from her first exam paper and one from the final exam project, the beginning and end of the trajectory can be considered, giving an impression of the influence of her participation in the programme. In the first exam paper, she presents important appraisals of her leadership approach, and indicates how this is to undergo deliberate change. Incidentally, and interestingly, this account is reproduced in a narrative presented by Eve in a subsequent qualitative interview.

Excerpt from Exam paper 1: "From January to October 2011 - after the implementation of the cluster - I made it clear to my staff that our new cluster manager was 'picking' at all our good work by making budgetary cuts, withdrawing our right to use temporary relief staff and asking us to cooperate with other institutions in order to cover each other's staff shortages. I focused on the changes being made, without being able to see any reason for them, and requested values and visions from the cluster leader, so that I could understand why the changes occurred. I was passing my own frustrations over a faltering sense of meaning in my work, onto the personnel."

Excerpt from final exam paper: "I am a big supporter of trust-based leadership, but have discovered that I need to exercise trust in a more reflected manner than I have had a tendency to, up until now. In the case of some of the employees, I have been too quick to grant them freedom, trusting that they could handle their tasks, and that they would approach me for assistance if in doubt. I have learned that I need to follow up more closely, study and support the different employees and teams. That some of the employees are co-managing (some perhaps tend to be self-managing) does not mean that everyone works in the same way." The excerpts suggest a marked change developing in Eve's understanding of her organisation, her staff and her leadership identity. While further and detailed 
Investigating the influence of a leadership development programme within the Danish public sector

analysis of the complete body of exam texts will give greater understanding of this trajectory, Eve can be seen to align herself to the official teaching curriculum within these - particularly to the concepts of systemic management and trust based leadership. Reflections on the application of these in practice gradually become observable in the exam papers, as illustrated in the excerpt from her final exam project.

\section{Shadowing Eve and the}

final exam project

Eve's changing approach, and how it is enacted in her iterative movement between the educational and organisational contexts is illustrated in her operationalisation of the final exam project in the LDP, and the manner in which she targets the empirical investigation. It was possible to plan shadowing intervals strategically around Eve's activities during this process, and to be present in the meetings and focus group interviews from which she collected empirical material. This provides a deeper and more detailed understanding of the goings on in the organisation - rather than solely relying on her accounts, or analysis of exam documents.

Eve bases her final exam project on the implementation and evaluation of team performance reviews within the $A$ house, replacing the individual reviews held previously. In both the final exam project, and a later qualitative interview Eve details how; through participation in an earlier module of the LDP ${ }^{8}$ focusing on the organisation of teams, she was introduced to the idea of conducting performance reviews collectively as a team, rather than individually. In light of radical organisational changes to the "A house" initiated by the cluster leader in 2013, involving the division of staff into larger and more binding teams, she found this to be instantly applicable to her own organisation, and an opportunity to encourage a cohesive approach to working with teams in the new structure. In her project, Eve evaluates her implementation of these team performance reviews, as a means of nurturing the new team system - in what can be seen as a deliberate attempt at supporting structural reforms. This, in itself reflects a change in her approach to such interventions.

Discussions arising between participants within one of these team performance reviews revealed conflicting approaches to fundamental tasks and very different understandings of what was to be deemed the correct professional pedagogical approach in given situations - particularly regarding the manner in which the children's dining situation should be conducted at lunchtime. The new team structure meant that these dining situations no longer involved the same, smaller group of children with the same team of pre-school teachers and assistants (pædagoger og medhjælper) organising their own room. Instead, this now involved a communal dining form, with different children assigned to different constellations of adults at each mealtime. This resulted in the team members' differing approaches to the dining situation becoming both apparent and problematic. The issues revealed within this initial team performance review gives rise to a series of meetings and a lengthy process aimed at reaching a productive consensus and a collective understanding of how to organise the dining situation. The field note below stems from observation of a team- planning meeting, a week after the original team performance review, where team members were invited to reflect upon their conflicting approaches and provide eventual reasons for them. Eve invites them to explain the differing positions regarding how the children should dine, with the participants articulating two different approaches. The first group firmly believes that the children should be as independent as possible, helping themselves to the available food. They describe this as a valuable learning opportunity, developing fine motor skills, turn taking and independence - the children should not be "serviced." The other group believes that they should firmly control the dining situation, allocating the available food and ensuring that the process is structured and efficient. They explain that this kind of coordination is essential, because - due to financial cutbacks, there is rarely enough of the most popular food. Therefore, if there is no control over the situation, the quickest children always hoard the popular food on their plates, leaving nothing for anyone else. They also explain that it is necessary to distribute the food, as otherwise the children will handle it excessively, raising concerns about hygiene. After the differing positions and opinions have been played out in full, Eve summarises and concludes this part of the meeting. She underlines that there can be no formal dining procedure, as there are too many factors which can influence which approach may be correct within the given situation - such as the group of children present, the staff involved, and the kind of food served. Eve and the team conclude that the situation demands alternation between the opposing positions, and individual flexibility in order to achieve this. 
Tema: Innovation og uddannelse

This situation provides an illustration of how Eve actively translates between the practices of the LDP and the organisation, how this is enacted, and potential influences on organisational practices. From the theoretical perspective provided by Lave and Wenger, Eve's learning curriculum, guided by the actualities of her organisational context, informs her investments and participation in the programme and the appropriation and application of particular resources offered, to meet the demands presented in the organisational context. The targeting of a particularly controversial area by Eve - the new team structureillustrates her commitment to using the LDP to engage with organisational challenges, and to bring the activities and understandings of the staff into focus. To assist the transition to the new team structure, she applies tools from the LDP, in order to encourage reflection and discussion about how they best can work within the new conditions. The introduction of the team performance review opens up for a shared forum, where collective responsibilities and individual obligations are discussed, encouraging the kind of debate and reflection which she perceives to be necessary for her staff to make sense of the new structure and accept their role within it. The ensuing debate reveals marked differences between the team members, attributable to fundamentally different understandings of the nature of their profession and the way they should approach their work, with Eve essentially mediating between them in an attempt to secure a shared approach and understanding within the team.

\section{In Summary}

The manner in which the individual leaders in the case-studies present and operationalise their participation in the LDP suggests that, although the LDP is essentially obligatory, it is not experienced as an intrusion, or an unwelcome regulation. Rather they openly embrace it as an opportunity to adapt themselves in a deliberate direction - in accordance with what they regard as the new organisational reality in the wake of ongoing structural reform. This reappraisal and acceptance of their position can be regarded as a preliminary finding, where further analysis of their exam papers will potentially lead to a more detailed understanding of how this is brought about. During the LDP, and upon completion of it, they are inspired to go on a "voyage of discovery" (a metaphor often used by the participants) within their own organisations. This is driven by a desire to gain a more detailed and accurate understanding of the issues affecting organisational life and practices - both internally and externally - in order to manage them in a more professional manner. In the case of Eve, participation in the educational and organisational practices can be seen to give rise to a shift in her approach, where frustrations with incessant reforms and changing demands appear to subside, now accepted as inevitable and to which she must adapt and position herself accordingly, with the LDP providing an opportunity to do so. The extent to which such active translation continues upon completion of the programme when there is no longer an explicit and structured demand to do so - remains to be seen, and will be central to the ongoing field studies. 
Investigating the influence of a leadership development programme within the Danish public sector

\section{REFERENCES}

Borgnakke, Karen. 1996. Pœdagogisk feltforskning og procesanalytisk kortlœgning - en forskningsberetning.

Brown, John Seely, and Paul Duguid. 2001. “Knowledge and Organization: A Social-Practice Perspective." Organization Science 12 (2): 198-213. doi:10.1287/orsc.12.2.198.10116.

Carroll, B., and L. Levy. 2010. “Leadership Development as Identity Construction." Management Communication Quarterly 24 (2): 211-31.

Carroll, Brigid, Lester Levy, and David Richmond. 2008. “Leadership as Practice: Challenging the Competency Paradigm." Leadership 4 (4): 363-79.

Cecchin, Daniela. 2008. Pædagogfaglige ledelse: om ledelse af pædagogiske institutioner. København: BUPL.

Conger, Jay Alden. 1992. Learning to Lead: The Art of Transforming Managers into Leaders. San Francisco: Jossey-Bass.

Danmarks Evalueringsinstitut. 2012. Lederuddannelsers betydning for ledelsespraksis: evaluering af offentlige lederes udbytte af lederuddannelser på diplomniveau. Kbh.: Danmarks Evalueringsinstitut.

Dreier, Ole. 2003. “Learning in Personal Trajectories of Participation." In Theoretical Psychology: Critical Contributions, edited by Niamh Stephenson. Concord, Ont., Canada: Captus University Publications.

Feldman, Martha S, and Wanda J Orlikowski. 2011. “Theorizing Practice and Practicing Theory." Orsc Organization Science 22 (5): 1240-53.

Gherardi, S. 2015. “To Start Practice Theorizing Anew: The Contribution of the Concepts of Agencement and Formativeness." Organization Organization.

Gherardi, Silvia, and Davide Nicolini. 2002. “Learning In A Constellation of Interconnected Practices: Canon or Dissonance?" J Management Studs Journal of Management Studies 39 (4): 419-36.

Hansbøl, Gorm. 2002. “Findes der en form for viden, der er særligt karakteristisk for pædagogisk ledelse?" In Professionalisering og ledelse, edited by Lejf Moos, Mads Hermansen, and John Krejsler. Frederikshavn: Dafolo.
Kempster, Steve. 2009. How Managers Have Learnt to Lead: Exploring the Development of Leadership Practice. Basingstoke [England]; New York: Palgrave Macmillan.

Klaudi Klausen, Kurt. 2008. “Ledelse som profession.” In Ledelse og læring - i organisationer, edited by Erik Elgaard Sørensen. Kbh.: Hans Reitzel.

Kofod, Klaus Kasper. 2002. “Ledelse og krav til ledere af de pædagogiske børne og ungeinstitutioner." In Professionalisering og ledelse, edited by Lejf Moos, Mads Hermansen, and John Krejsler. Frederikshavn: Dafolo.

Larsen Nielsen, Inger Marie. 2009. Daginstitutionsledelse: profession og ledelse. Kbh.: Hans Reitzel.

Lave, Jean, and Etienne Wenger. 1991. Situated Learning: Legitimate Peripheral Participation. Cambridge [England]; New York: Cambridge University Press.

Lord, Robert G, and Rosalie J Hall. 2005. “Identity, Deep Structure and the Development of Leadership Skill." The Leadership Quarterly The Leadership Quarterly 16 (4): 591-615.

Marcus, George E. 1995. “Ethnography In/of the World System: The Emergence of Multi-Sited Ethnography." Annual Review of Anthropology 24: 95-117.

Nicholson, H, and B Carroll. 2013. "Identity Undoing and Power Relations in Leadership Development." HUMAN RELATIONS -NEW YORK- 66 (9): 1225-48.

Nicolini, Davide. 2012. Practice Theory, Work, and Organization an Introduction. Oxford: Oxford University Press.

Porter, Lyman W, and Grace B McLaughlin. 2006. “Leadership and the Organizational Context: Like the Weather?" The Leadership Quarterly The Leadership Quarterly 17 (6): 559-76.

Reckwitz, Andreas. 2002. "Toward a Theory of Social Practices A Development in Culturalist Theorizing." European Journal of Social Theory 5 (2): 243-63.

Regeringen, ed. 2007. Bedre velfærd og større arbejdsglæde: regeringens strategi for høj kvalitet i den offentlige service. København.

Rennison, Betina W. 2010. “Ledelsens genealogi: offentlig ledelse fra tabu til trend." Frederiksberg: Samfundslitteratur. 
Tema: Innovation og uddannelse

\section{ENDNOTES}

Schatzki, Theodore. 2002. The Site of the Social a Philosophical Account of the Constitution of Social Life and Change. University Park: Pennsylvania State University Press. http://site.ebrary.com/id/10532227.

Weinreich, Elvi, Copenhagen Business School. CBS, Department of Operations Management. OM, Institut for Produktion og Erhvervsøkonomi. PEØ, and LIMAC PhD School. 2014. Hvilke offentlige ledere er der brug for når velfærdstænkningen flytter sig: Er Diplomuddannelsens lederprofil svaret?. Frederiksberg.

Wenger, Etienne. 1998. Communities of Practice: Learning, Meaning, and Identity. Cambridge, U.K.; New York, N.Y.:

Cambridge University Press.

Whittington, Richard. 2003. “The work of strategizing and organizing: for a practice perspective." Strategic Organization 1 (1): 117-25.
1 Information sourced from a newsletter originally published on the Municipality of Copenhagen website. Accessed at www.Ifs.dk/5453 (19.112015)

2 Ny institutionsstruktur. Hvidbog for klynger - Et overblik over snitflader, rammer og retningslinjer 1. udgave - april 2011 www.Ifs.dk/files/3/62/hvidbog_klynger.pdf (accessed18.12.2015)

3 "Grundfortælling om klyngeledelse i Københavns kommune - januar 2014." https://nemboern.kbhbarn.kk.dk/FrontEnd.aspx?id=922341

4 www.kk.dk/sites/default/files/edoc/bcf45284-f735-43b5-b8139da7bcda61ad/a141a3bd-f3d0-49ae-b4a7-8007065d9030/ Attachments/10309897-10056878-1.PDF (Accessed 02.01.2016)

5 Studieordning for Diplomuddannelsen I ledelse: http://diplom. uc-dk.dk/images/Studieordning_for_Diplomuddannelsen_i_ledelse_ okt__2015.compressed.pdf (Accessed 09.12.15)

6 www.phmetropol.dk/Om+Metropol/Nyheder+og+Presse/ Nyheder/2014/08/samarbejde+med+Koebenhavns+Kommune (accessed 02.01.2016)

7 “Tillidsreformen i social forvaltningen." Københavns Kommune: http://modernisering.nu/media/613852/tillidsreformen_i_ socialforvaltningen.pdf (Accessed 05.01.15)

8 "On my elective course 'Management of Network and teams,' in the autumn of 2014, I was inspired - we should hold team-performance interviews in our cluster. Final exam paper. 